This document was prepared in conjunction with work accomplished under Contract No. DE-AC09-96SR18500 with the U.S. Department of Energy.

This work was prepared under an agreement with and funded by the U.S. Government. Neither the U. S. Government or its employees, nor any of its contractors, subcontractors or their employees, makes any express or implied: 1 . warranty or assumes any legal liability for the accuracy, completeness, or for the use or results of such use of any information, product, or process disclosed; or 2 . representation that such use or results of such use would not infringe privately owned rights; or 3 . endorsement or recommendation of any specifically identified commercial product, process, or service. Any views and opinions of authors expressed in this work do not necessarily state or reflect those of the United States Government, or its contractors, or subcontractors. 
WSRC-TR-2006-00171, Rev. 0

Keywords: Waste processing, solvent extraction

Retention: Permanent

\title{
SOLVENT FIRE BY-PRODUCTS
}

\author{
D. D. Walker and S. D. Fink
}

May 22, 2006

Savannah River National Laboratory

Washington Savannah River Company

Savannah River Site

Aiken, SC 29808

Prepared for the U.S. Department of Energy Under

Contract Number DE-AC09-96SR18500

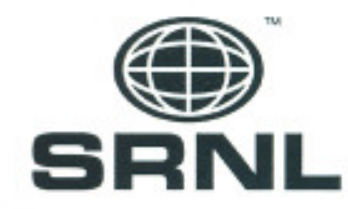




\section{REVIEWS AND APPROVALS}

\section{Authors:}

D. D. Walker, SRNL Process Chemistry and Science

$\frac{5 / 22 / 06}{\text { Date }}$

Technical review:

C. A. Nash, SRNL Process Chemistry and Science

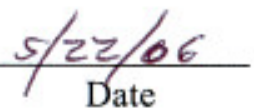

\section{SRNL Management:}

S. D. Fink, Manager, SRNL Process Chemistry and Science

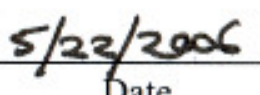

$\begin{array}{lc}\text { J. C. Griffin, Manager, SRNL Chemical Science \& Technology } & 6 / 1 / 2006 \\ \text { Date }\end{array}$

\section{Customer:}

K. P. Burrows, Manager, MCU Design Authority

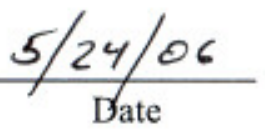




\subsection{EXECUTIVE SUMMARY}

Southwest Research Institute (SwRI) conducted a burn test of the Caustic-Side Solvent Extraction (CSSX) solvent to determine the combustion products. The testing showed hydrogen fluoride gas is not a combustion product from a solvent fire when up to $70 \%$ of the solvent is consumed. The absence of HF in the combustion gases may reflect concentration of the modifier containing the fluoride groups in the unburned portion. SwRI reported results for other gases $(\mathrm{CO}, \mathrm{HCN}, \mathrm{NOx}$, formaldehyde, and hydrocarbons). The results, with other supporting information, can be used for evaluating the consequences of a facility fire involving the CSSX solvent inventory.

\subsection{INTRODUCTION}

The Department of Energy (DOE) identified the CSSX process as the preferred technology to remove cesium from radioactive waste solutions at the Savannah River Site (SRS). ${ }^{1,2}$ As a result, Washington Savannah River Company (WSRC) began designing and building a Modular CSSX Unit (MCU) in the SRS tank farm to process liquid waste for an interim period until the Salt Waste Processing Facility (SWPF) begins operations. Both the MCU and SWPF use the CSSX technology although the facilities differ in size and processing rate.

The CSSX process uses a solvent system composed of four chemicals (Table I). The solvent contains approximately $70 \mathrm{wt} \%$ Isopar ${ }^{\circledR} \mathrm{L}$ diluent. Isopar ${ }^{\circledR} \mathrm{L}$ is an isoparaffinic hydrocarbon blend comprised principally of alkanes containing 10- to 12-carbon atoms. The solvent is combustible with a flash point of $148{ }^{\circ} \mathrm{F}^{3}$ Due to its combustibility, solvent fires are a potential process hazard. To fully evaluate the consequences, we need to know the by-product gases produced during a solvent fire.

In this task, SRNL researchers subcontracted with Southwest Research Institute (SwRI) in San Antonio, Texas, to burn a sample of CSSX solvent using standard test protocols. This document contains the SwRI report (Appendix A), additional test data (Appendix B), details of the solvent sample used in testing, and information calculated from the SwRI report.

This task addresses the scope described in the technical task request titled "Determine the MCU solvent mixture fire by-products"4 and followed the requirements of the "Task Technical and Quality Assurance Plan for Determining Solvent Combustion By-Products." ${ }^{5}$

\subsection{EXPERIMENTAL DETAILS}

CSSX solvent ( $350 \mathrm{~mL}$, Batch \#S2-D1-YES BOB-T-WI ${ }^{6}$ with the composition listed in Table I, was contacted with $50 \mathrm{~mL}$ of Optima salt solution (Table II) in a separatory funnel for 2 minutes to saturate the solvent with water and nitrate ion. The salt solution was removed and the solvent was packaged and sent to SwRI labeled as "CSSX Solvent". The nominal solvent density equals $0.85 \mathrm{~g} / \mathrm{mL}$ at $25^{\circ} \mathrm{C} .{ }^{6}$

Appendix A contains the report provided by SwRI. Testing occurred in a fire chamber described in ASTM International Standard E 1995, "Measurement of Smoke Obscuration Using a Conical 
TABLE I. Composition of CSSX Solvent.

\begin{tabular}{|l|l|}
\hline \multicolumn{1}{|c|}{ Component* } & \multicolumn{1}{c|}{ Concentration (molar) } \\
\hline Extractant (BOBCalixC6) & 0.0070 \\
\hline Modifier (Cs-7SB) & 0.75 \\
\hline Tri-n-octyl amine & 0.0030 \\
\hline Diluent (Isopar ${ }^{\circledR}$ L) & (balance) \\
\hline
\end{tabular}

* BOBCalixC6 = Calix[4]arene-bis(tert-octylbenzo-crown-6); Cs-7SB = 1-(2,2,3,3-tetrafluoropropoxy) -3-(4-sec-butylphenoxy)-2-propanol.

\section{TABLE II. Composition of Optima Salt Solution}

\begin{tabular}{lc} 
Component & Concentration (molar) \\
\cline { 1 - 2 } $\mathrm{Na}^{+}$ & 5. \\
$\mathrm{~K}^{+}$ & 0.015 \\
$\mathrm{OH}^{-}$ & 2.0 \\
$\mathrm{NO}_{3}{ }^{-}$ & 2.0 \\
$\mathrm{NO}_{2}{ }^{-}$ & 0.49 \\
$\mathrm{AlO}_{2}{ }^{-}$ & 0.29 \\
$\mathrm{CO}_{3}{ }^{2-}$ & 0.15 \\
$\mathrm{SO}_{4}{ }^{2-}$ & 0.14 \\
$\mathrm{Cl}^{-}$ & 0.023 \\
$\mathrm{~F}^{-}$ & 0.027 \\
$\mathrm{PO}_{4}{ }^{3-}$ & 0.007 \\
$\mathrm{oxalate}^{2-}$ & 0.008 \\
$\mathrm{SiO}_{3}{ }^{-}$ & 0.03 \\
$\mathrm{MoO}_{4}^{-}$ & 0.00007
\end{tabular}

Radiant Source in a Single Closed Chamber, With the Test Specimen Oriented Horizontally". This standard allows combustion in a horizontal cup that can hold a liquid sample. The fire chamber measured $914 \mathrm{~mm}$ x $914 \mathrm{~mm}$ x $610 \mathrm{~mm}$, yielding a chamber volume of $0.51 \mathrm{~m}^{3}$. The sample was heated at $25 \mathrm{~kW} / \mathrm{m}^{2}$ using a radiant heater. Ignition by small propane flame over the sample occurred within 12 seconds of the start of radiant heating. The combustion box collects all of the gases from the burning sample and the accumulated gases were analyzed by drawing portions through Draeger tubes after 4 minutes from the start of heating. The fire selfextinguished at approximately the same time at which sampling occurred (Appendix B), leaving a viscous residue. The initial and final sample weights were measured and recorded per the standard. An SwRI researcher provided the weight data (Appendix B) that was not contained in the final report. Laboratory Notebook \#WSRC-NB-2003-00141, pp 94-102, contains details of the sample preparation and copies of the memoranda containing the mass loss data and observations summarized in Appendix B. 


\subsection{RESULTS}

The SwRI tests measured carbon monoxide $(\mathrm{CO})$, hydrogen cyanide $(\mathrm{HCN})$, hydrogen fluoride $(\mathrm{HF})$, nitrogen oxides ( $\mathrm{NO}$ and $\mathrm{NO}_{2}$ ), formaldehyde $\left(\mathrm{CH}_{2} \mathrm{O}\right)$ and general hydrocarbon concentrations in the combustion gases. Table III lists the measured results and values calculated from them. The gas concentration in ppm (by volume) reported by SwRI were converted to "mg/L" using the molecular weights of the individual gases and assuming the ideal gas law. To apply the ideal gas law, the combustion box temperature was assumed equal to $23{ }^{\circ} \mathrm{C}$. The gases in the combustion box are not isothermal since a portion of the box is occupied by a flame. Since the average temperature likely exceeded $23{ }^{\circ} \mathrm{C}$, the calculated values in these units are conservatively overestimated. Combining the calculated concentrations (in "mg/L") with the amounts of sample burned produced the by-product yields in units of "grams of gas per liter of solvent consumed". Appendix C contains a sample calculation. Table III does not include the by-product yields for the hydrocarbons because the measured concentrations imply more hydrocarbons in the vapor phase than were present in the original sample. This overestimation may be due to the gas temperature assumption mentioned above, or breakdown of the larger hydrocarbons to smaller fragments. Since the tests consumed between 60 and $70 \%$ of the initial sample, the results apply to burning (or consuming) the initial $1.0 \mathrm{~L}$ from a $1.42 \mathrm{~L}$ sample.

TABLE III. Combustion Gas Compositions and Source Terms

\begin{tabular}{|c|c|c|c|c|c|c|}
\hline & \multicolumn{6}{|c|}{ Component Concentration } \\
\hline & \multicolumn{6}{|c|}{ Gas Concentration - Measured (ppm by volume) } \\
\hline Test Run & $\mathrm{CO}$ & $\mathrm{HCN}$ & HF & $\mathbf{N O}_{\mathrm{x}}$ & $\mathrm{CH}_{2} \mathrm{O}$ & Hydrocarbons \\
\hline 1 & 2000 & 5 & $<1.5$ & Trace & $>40$ & $>13,000$ \\
\hline 2 & 500 & 2 & $<1.5$ & 5 & 2 & $>13,000$ \\
\hline \multirow[t]{2}{*}{3} & 2000 & 5 & $<1.5$ & 5 & $>40$ & $>13,000$ \\
\hline & \multicolumn{6}{|c|}{ Gas Concentration - Calculated (mg/L)* } \\
\hline 1 & 2.3 & 0.0056 & $<0.0012$ & Trace & $>0.05$ & $>91$ \\
\hline 2 & 0.6 & 0.0022 & $<0.0012$ & 0.0095 & 0.0025 & $>91$ \\
\hline \multirow[t]{2}{*}{3} & 2.3 & 0.0056 & $<0.0012$ & 0.0095 & $>0.05$ & $>91$ \\
\hline & \multicolumn{6}{|c|}{ By-product Yield - Calculated (g per liter of solvent consumed) $* *$} \\
\hline 1 & 47 & 0.11 & $<0.024$ & Trace & $>1.0$ & $* * *$ \\
\hline 2 & 13 & 0.05 & $<0.028$ & 0.22 & 0.06 & $* * *$ \\
\hline 3 & 57 & 0.14 & $<0.030$ & 0.23 & $>1.2$ & $* * *$ \\
\hline \multicolumn{7}{|c|}{$\begin{array}{l}\text { * Assuming gas temperature of ideal gas behavior, gas temperature of } 23^{\circ} \mathrm{C}, \mathrm{NO}_{\mathrm{x}} \text { as } \\
\mathrm{NO}_{2} \text {, and Hydrocarbons as } \mathrm{C}_{12} \mathrm{H}_{26} \text {. } \\
* * \text { Derived from the calculated gas concentrations, weight loss of samples upon burning } \\
\text { (Appendix B), solvent density of } 0.85 \mathrm{~g} / \mathrm{mL} \text {, and volume of the burn box }\left(0.51 \mathrm{~m}^{3}\right) \text {. } \\
\text { Note that the amount of solvent consumed (i.e., the weight loss) in these tests was } \\
60-70 \% \text { of the amount present. } \\
* * * \text { Not calculated. See discussion in text. }\end{array}$} \\
\hline
\end{tabular}


In general, researchers expected the combustion gases that were observed. The hydrocarbons, formaldehyde and carbon monoxide arise from evaporation or partial combustion of the solvent. The tri-octylamine or nitrate salts in the solvent, or nitrogen gas in air provide potential sources of nitrogen for the small amounts of $\mathrm{HCN}$ and $\mathrm{NO}_{\mathrm{x}}$.

Hydrogen fluoride concentrations in the combustion gases failed to reach the Draeger tube detection limit of $1.5 \mathrm{ppmv}$. This result was unexpected since the modifier compound contains a $-\mathrm{O}-\mathrm{CH}_{2}-\mathrm{CF}_{2}-\mathrm{CF}_{2} \mathrm{H}$ side chain that can produce $\mathrm{HF}$ during combustion. The low $\mathrm{HF}$ yield and other observations suggest that Isopar ${ }^{\circledR}$ L burned, leaving behind the less volatile modifier compound. Observers noted that the flame self-extinguished after $\sim 4$ minutes. The proximity to the time of sampling the gas was coincidental. The 30-40 wt \% of the sample that remained in the residue approximately equals the modifier content of solvent (30 wt \%). However, the decreasing oxygen concentration in the burn box may also contribute to the incomplete combustion. A material balance between the available oxygen in the burn box and the size of the solvent sample suggests insufficient oxygen was present for complete combustion. Partial combustion may have produced fluorocarbon fragments rather than complete oxidation to HF. Thus, the low $\mathrm{HF}$ yield observed in these tests applies to fires of similar general conditions (including completeness of burn) as tested.

\subsection{CONCLUSIONS}

Burn tests of the CSSX solvent confirmed the presence of carbon monoxide, formaldehyde, hydrogen cyanide, nitrogen oxides, and hydrocarbons in the combustion gases. Testing did not find hydrogen fluoride above the detection limit of $1.5 \mathrm{ppmv}$. The absence of HF in the combustion gases and other observations suggest the modifier component of the solvent (containing the fluorine-substituted groups) became enriched in the unburned portion of the solvent sample. These results, with other supporting information, can be used for evaluating the consequences of a facility fire involving the CSSX solvent inventory.

\subsection{REFERENCES}

\footnotetext{
${ }^{1}$ C. L. Huntoon to G. P. Rudy, memorandum titled "Preferred Alternative for the Savannah River Salt Processing Project", June 25, 2001.

${ }^{2}$ R. A. Dimenna et al., "Bases, Assumptions, and Results of the Flowsheet Calculations for the Decision Phase Salt Disposition Alternatives", WSRC-RP-99-00006, Rev. 3, May 24, 2001.

${ }^{3}$ R. J. Ray and D. D. Walker, "Flash Point of CSSX Solvent," WSRC-TR-2006-00083, Rev. 0, March 1, 2006.

${ }^{4}$ S. Shah, Technical Task Request, "Measurement of Evaporation Rate for Isopar ${ }^{\circledR}$ L," SP-TTR-2005-00001-S, February 9, 2006.

${ }^{5}$ D. D. Walker and S. D. Fink, "Task Technical and Quality Assurance Plan for Determining Solvent Combustion By-Products," WSRC-RP-2006-00498, Rev. 0, March 20, 2006.

${ }^{6}$ K. Adu-Wusu, D. D. Walker, T. L. White, and S. L. Crump, "Preparation of Caustic-Side Solvent Extraction (CSSX) Solvent with BOBCalixC6 for Wright Industries - Component Amounts, Analytical and Quality Assurance Results," SRNL-WPT-2005-00134, December 2, 2005..
} 
WSRC-TR-2006-00171, Rev. 0

Page 7 of 14

APPENDIX A: Test Report from SwRI 


\section{S O U T H W E T RESEARCH IN T T T U T E}

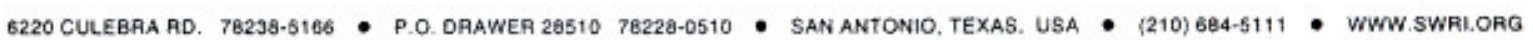
CHEMISTRY ANO CHEMICAL ENGINEERING DIVISION DEPARTMENT OF FIRE TECHNOLOGY WWW FIRE SWRIORG FAX 210/522-3377

TOXICITY Evaluation

OF CSSX SOLVENT TESTED IN

GENERAL ACCORDANCE WITH BSS 7239

FINAL REPORT

Consisting of 5 Pages

SwRI ${ }^{\circledast}$ Project No. 01.12272.01.001

DOE Contract No. DE-ACO9-96SR18500

DOE Order No. aA46873N

April 2006

Prepared for:

Washington Savannah River Company

Building 731-1N Operations Receiving

Aiken, SC 29808

Submitted by:

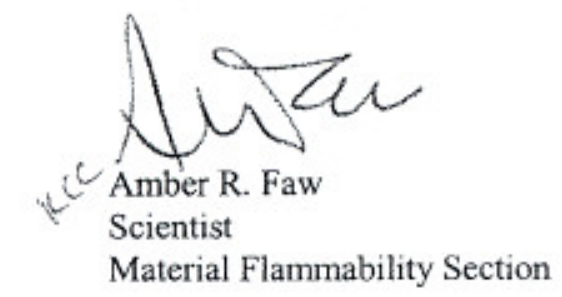

Approved by:

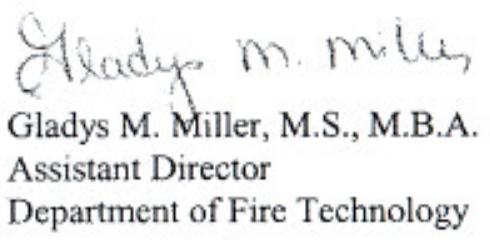




\begin{abstract}
Washington Savannah River Company located in Aiken, South Carolina, submitted a material identified as CSSX Solvent for testing in general accordance with BSS 7239, Test Method for Toxic Gas Generation by Materials on Combustion. ASTM International E 662/BSS 7238 describes the smoke density chamber that is used for sample exposure and toxicity analysis under BSS 7239. Because this was a liquid sample, testing was carried out in the smoke density chamber described in ASTM International E 1995, which has a horizontally oriented sample cup.

Testing was performed in triplicate at a heat flux of $25 \mathrm{~kW} / \mathrm{m}^{2}$ in accordance with BSS 7239 . Maximum toxic gas concentrations are presented in parts per million (ppm) as derived from the colorimetric tubes (see table below). Detailed toxicity values are presented in the text.
\end{abstract}

CSSX SOLVENT PERFORMANCE SUMMARY.

\begin{tabular}{|c|c|c|c|c|c|c|}
\hline Toxic Gas & CO & HCN & HF & NO & Formaldehyde & Hydrocarbons \\
\hline \multirow{3}{*}{$\begin{array}{c}\text { Result } \\
\text { (ppm) }\end{array}$} & 2,000 & 5 & Not Detected & Trace & $>40$ & $>13,000$ \\
\cline { 2 - 7 } & 500 & 2 & Not Detected & 5 & 2 & $>13,000$ \\
\cline { 2 - 7 } & 2,000 & 5 & Not Detected & 5 & $>40$ & $>13,000$ \\
\hline
\end{tabular}


WSRC-TR-2006-00171, Rev. 0

Page 10 of 14

TABLE OF CONTENTS

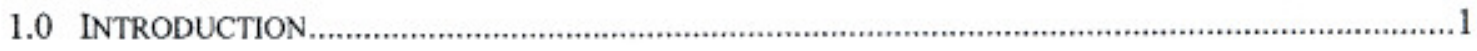

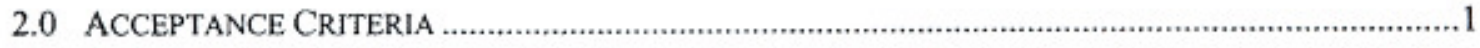

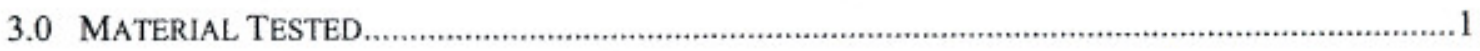

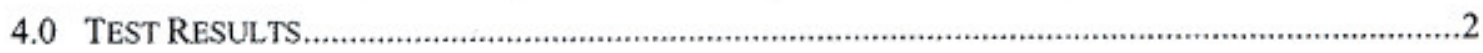




\subsection{INTRODUCTION}

This report presents the results of a toxicity test conducted at Southwest Research Institute's (SwRI) Department of Fire Technology, located in San Antonio, Texas. The test was conducted in general accordance with the procedures outlined in Boeing Specification Support Standard BSS 7239 (1988), Test Method for Toxic Gas Generation by Materials on Combustion. Gases specifically covered per Client request for this analysis include carbon monoxide $(\mathrm{CO})$, hydrogen cyanide $(\mathrm{HCN})$, nitrogen oxides $\left(\mathrm{NO}_{\mathrm{x}}\right)$, hydrogen fluoride $(\mathrm{HF})$, formaldehyde $\left(\mathrm{CH}_{2} \mathrm{O}\right)$, and general hydrocarbon content.

ASTM International E 662/ BSS 7238 describes the smoke density chamber that is used for sample exposure and toxicity analysis under BSS 7239. Specimens measuring $76.2 \times 76.2 \mathrm{~mm}$ (nominal $3 \times 3 \mathrm{in}$.) are tested in the vertical orientation, while exposed to a radiant heat flux of $25 \mathrm{~kW} / \mathrm{m}^{2}$. Specimens are exposed in the flaming mode only. Because this was a liquid sample, testing was carried out in the smoke density chamber described in ASTM International E 1995, which has a horizontally oriented sample cup. The exposure was $25 \mathrm{~kW} / \mathrm{m}^{2}$ in the flaming mode.

Unless otherwise specified, gas is sampled $240 \mathrm{sec}(4 \mathrm{~min})$ into the exposure period. A vacuum apparatus draws smoke and gases into a flexible plastic container. Gas colorimetric (Dräger) tubes are used to analyze smoke sampled and are attached to a Dräger hand pump, which is connected to the plastic sample collection bags. Two specimens are analyzed from the flaming exposure. If the observed concentration from the second sample varies by more than $50 \%$ from the first, a third sample is evaluated.

This test method is intended to measure and describe the properties of products in response to heat and flame under controlled laboratory conditions. The results should not be used alone to describe or appraise the fire hazard or the fire risk of materials, products, or assemblies under actual fire conditions. However, results of this test may be used as elements of a complete fire hazard assessment or a fire risk assessment, which takes into account all the factors that are pertinent to an assessment of the fire hazard or fire risk of a particular end use. The results apply specifically to the specimens tested, in the manner tested, and not to similar materials, nor to the performance when used in combination with other materials.

\subsection{ACCEPTANCE CRITERIA}

No acceptance criteria for toxic gas concentrations are published in the BSS 7239 standard, nor were any provided by the client.

\subsection{MATERIAL TESTED}

Washington Savannah River Company, located in Aiken, South Carolina, provided one bottle of a combustible liquid specimen identified as CSSX Solvent, which was received by SwRI on March 31, 2006, and weighed approximately $400 \mathrm{~g}$ (see Table 1). The specimen bottle was placed in a flammable liquids 
cabinet from the time it was received until just prior to testing. This was a necessary deviation from the standard which requires that the materials be placed in a conditioned environment maintained at $73 \pm 5^{\circ} \mathrm{F}$ $\left(23 \pm 3^{\circ} \mathrm{C}\right)$ and a relative humidity of $50 \pm 5 \%$ from the time they were received until just prior to testing.

TABle 1. CSSX SOLVENT TeSt SAMPLe Description PRovided BY the Client.

\begin{tabular}{||c|c|c|c|c|}
\hline \hline Material ID & $\begin{array}{c}\text { Description of } \\
\text { Material }\end{array}$ & Chemical Name & Percent & CAS \# \\
\hline \multirow{3}{*}{$\begin{array}{c}\text { CSSX } \\
\text { Solvent }\end{array}$} & \multirow{2}{*}{$\begin{array}{c}\text { Four part } \\
\text { solvent }\end{array}$} & $\begin{array}{c}\text { Calix[4]arene-bis- (tertoctylbenzo-crown-6) } \\
\text { (BOBCalixC6) }\end{array}$ & 0.94 & Not available \\
\cline { 3 - 5 } & & $\begin{array}{c}\text { 2-pronaol,1-(2,2,3,3-tetrafluoropropoxy)-3-3(4- } \\
\text { secbutylphenoxy)(CS-7SB Modifier) }\end{array}$ & 29.8 & $308362-88-1$ \\
\cline { 3 - 5 } & & Trioctylamine & 0.12 & $1116-76-3$ \\
\cline { 3 - 5 } & Isopar L & 69.14 & $64742-48-9$ \\
\hline
\end{tabular}

\subsection{TEST RESULTS}

The tests were conducted on April 14,2006, in general accordance with BSS 7239, toxic gas generation. If the observed concentration from the second sample varies by more than $50 \%$ from the first, a third sample is evaluated. In accordance with the standard, three tests were performed. Toxic gas results are summarized in Table 2.

TABLE 2. TEST RESULTS FOR CSSXSOLVENT.

\begin{tabular}{|c|c|c|c|c|c|}
\hline Toxic Gas & $\begin{array}{c}\text { Colorimetric } \\
\text { Gas Detector } \\
\text { Tube No. }\end{array}$ & $\begin{array}{l}\text { Run } \\
\text { No. }\end{array}$ & $\begin{array}{c}\text { Measuring } \\
\text { Range } \\
\text { (ppm) }\end{array}$ & $\begin{array}{l}\text { Number of } \\
\text { Strokes }\end{array}$ & Result (ppm) \\
\hline \multirow{3}{*}{$\mathrm{CO}$} & \multirow{3}{*}{$10 / \mathrm{b}$} & 1 & \multirow{3}{*}{$100-3,000$} & \multirow{3}{*}{1} & 2,000 \\
\hline & & 2 & & & 500 \\
\hline & & 3 & & & 2,000 \\
\hline \multirow{3}{*}{$\mathrm{HCN}$} & \multirow{3}{*}{$2 / \mathrm{a}$} & 1 & \multirow{3}{*}{$2-30$} & 1 & 5 \\
\hline & & 2 & & 5 & 2 \\
\hline & & 3 & & 1 & 5 \\
\hline \multirow{3}{*}{$\mathrm{HF}$} & \multirow{3}{*}{$1.5 / \mathrm{b}$} & 1 & \multirow{3}{*}{$1.5-15$} & \multirow{3}{*}{20} & Not Detected \\
\hline & & 2 & & & Not Detected \\
\hline & & 3 & & & Not Detected \\
\hline \multirow{3}{*}{$\mathrm{NO}_{x}$} & \multirow{3}{*}{$2 / \mathrm{a}$} & 1 & \multirow{3}{*}{$2-50$} & \multirow{3}{*}{10} & Trace \\
\hline & & 2 & & & 5 \\
\hline & & 3 & & & 5 \\
\hline \multirow{3}{*}{$\mathrm{CH}_{2} \mathrm{O}$} & \multirow{3}{*}{$2 / a$} & 1 & \multirow{3}{*}{$2-40$} & \multirow{3}{*}{5} & $>40$ \\
\hline & & 2 & & & 2 \\
\hline & & 3 & & & $>40$ \\
\hline \multirow{3}{*}{ Hydrocarbons } & \multirow{3}{*}{$0.1 \% / \mathrm{b}$} & 1 & \multirow{3}{*}{$\begin{array}{c}1000 \\
- \\
13,000\end{array}$} & \multirow{3}{*}{10} & $>13,000$ \\
\hline & & 2 & & & $>13,000$ \\
\hline & & 3. & & & $>13,000$ \\
\hline
\end{tabular}




\section{APPENDIX B: Additional Data from SwRI}

Amber R. Faw, Southwest Research Institute, provided the following mass loss data for the three test runs.

\begin{tabular}{|c|c|c|c|c|}
\hline Test Run & Start $(\mathbf{g})$ & End $(\mathbf{g})$ & Mass Loss $(\mathbf{g})$ & Mass Loss (\%) \\
\hline 1 & 44.60 & 13.76 & 30.84 & 69 \\
\hline 2 & 46.49 & 16.91 & 29.58 & 64 \\
\hline 3 & 46.92 & 18.20 & 28.72 & 61 \\
\hline
\end{tabular}

Additional test data obtained from SwRI includes the following observations.

- The samples self-extinguished after the following durations. Coincidentally, this occurred at approximately the time of sampling.

$\begin{array}{cc}\frac{\text { Test Run }}{1} & \text { Duration (min:sec) } \\ 2 & 3: 55 \\ 3 & 3: 52 \\ 4: 10\end{array}$

- A thick, viscous residue remained after burning the samples. 


\section{APPENDIX C: Example of Calculated Values}

Researchers calculated values of concentration (in $\mathrm{mg} / \mathrm{L}$ ) and by-product yields (in g per liter of solvent burned) as follows. Carbon monoxide serves at the example.

CO concentration:

Temperature:

Volume of 1 mole of ideal gas at $23{ }^{\circ} \mathrm{C}$ :

Molecular weight of CO:

Volume of combustion gas:

Mass of sample burned:

Density of solvent:

Fraction consumed:
$2000 \mathrm{ppm}$ by volume or 0.2 vol \%

$23{ }^{\circ} \mathrm{C}$ or $296^{\circ} \mathrm{K}$.

$24.3 \mathrm{~L}$

$28 \mathrm{~g} / \mathrm{mole}$

$0.51 \mathrm{~m}^{3}$ or $510 \mathrm{~L}$

$30.84 \mathrm{~g}$

$0.852 \mathrm{~g} / \mathrm{mL}$ or $852 \mathrm{~g} / \mathrm{L}$

$69.1 \%$

$$
\begin{aligned}
\text { Concentration of CO }(\mathrm{mg} / \mathrm{L}) & =\frac{0.002 \mathrm{~L} \text { of CO }}{\mathrm{L} \text { of combustion gas }} \times \frac{28 \mathrm{~g} \text { of CO }}{\text { mole CO}} \times \frac{1 \text { mole CO }}{24.3 \mathrm{~L} \mathrm{of} \mathrm{CO}} \\
& =0.0023 \mathrm{~g} / \mathrm{L} \text { or } 2.3 \mathrm{mg} / \mathrm{L}
\end{aligned}
$$

By-product yield $(\mathrm{g} / \mathrm{L}$ of solvent $)=\underline{(0.0023 \mathrm{~g} / \mathrm{L}) \times 510 \mathrm{~L}}$

$$
(3.84 \mathrm{~g} / 852 \mathrm{~g} / \mathrm{L}) \times(0.691)
$$

$=47 \mathrm{~g} \mathrm{CO}$ per L of solvent burned 